\title{
Edukacja środowiskowa w zadaniach rodziny
}

\begin{abstract}
Wstęp
Według Ranhera „stosunek do świata i przyrody urzeczywistnia się w wewnętrznym życiu wiary, sumienia, modlitwy, ale również w świecie i jej materii” ${ }^{1}$.

W wychowaniu, w przygotowaniu do współżycia z przyrodą i do szanowania ludzkiego środowiska życia, ważna jest droga jaką powinien przebyć człowiek od momentu poczęcia do momentu osiągnięcia zintegrowanej osobowości, takiej, aby w praktyce codziennego życia realizował poprzez swoje zmotywowane postawy „dojrzały światopogląd ekologiczny”. Nie powinniśmy zapominać, że to osoba i jej środowisko życia wychowuję osobę, a nie wartości i metody. Rodzina wspólnie poszukująca prawdy i odkrywająca ją zaczyna rozumieć, że nie ma gotowych rozwiązań i wszelkim formalnym procesom musi towarzyszyć dynamizm i twórcze działanie. Stajemy się na nowo każdego dnia, pamiętając o tym możemy ustrzec się przed skostnieniem i przyzwyczajeniami, które hamują drogę do prawdy i wolności.

„Przyroda dla dzisiejszego człowieka nie jest już wspaniałą, niepodległą mu namiestniczą Boga, lecz materiałem, którego potrzebuje, by budować sobie, według własnych praw własny świat, by doświadczać siebie w swojej, wolnej twórczości”2. Aby tak się nie działo, musimy w naszych rodzinach i w naszych szkołach przyjąć nowe wyzwania w dziedzinie wychowywania młodego pokolenia.

Rahner w swoich rozważaniach mówi: „Zakładam, że trzeba by mieć powody, aby się zmienić, idąc przeciw prawu, zgodnie z którym wstępowało się w życie. Ktoś, kto zmieniłby się bez takich powodów, kto nie zamierzałby, początkowo, pozostać wiernym swej danej sytuacji istnienia, temu co w jego osobie duchowej już dokonane, byłby człowiekiem lecącym w próżnię, zdolnym stawać się tylko coraz większą wewnętrzną ruiną. Jeśli człowiek nie ma zrzec się w końcu samego siebie, to, co jest mu dane, musi być w zasadzie szanowane jako coś, co należy
\end{abstract}

K. Rahner, O mozliwości wiary dzisiaj, 1983, s.46.

2 K. Rahner, O moźliwość wiary dzisiaj, 1983, s.46 
przyjąć i strzec, póki nie ma dowodów przeciw temu. Żyć i rosnąć można tylko od korzenia, który już żje i rozwija się, tylko od jakiegoś początku, ogniskującego elementarne zaufanie do istnienia"3.

W tym, co pisze Rahner widać nadzieję mocy korzenia, a tym korzeniem jest i powinna być rodzina. Zdrowa silna rodzina pomimo prób, różnych niepowodzeń i trudności ma duże szansę zaopatrzyć młodego człowieka w życiodajne soki mądrości i wiary, w taki sposób, aby ten nie chciał i nie miał powodów odchodzić od źródła swojej tożsamości.

\section{Czynniki wpływające na kształtowanie człowieka}

Składnikami środowiska są otoczenie i doświadczenie. Zachowanie jednostki jest determinowane doświadczeniem, które wywodzi się z jej kontaktów z otoczeniem. Pomiędzy otoczenie przyrodnicze a jednostkę zawsze wkracza środowisko społeczne. Wzajemne oddziaływania jednostki i otoczenia mają wpływ na formowanie i kształtowanie jej osobowości. Charakterystyczną cechą jest to, że społeczeństwo istnieje dłużej niż jednostka. To jednostka zostaje włączona do organizacji, która już funkcjonuje. Pomimo tego, że powstają nowe społeczeństwa, to większość ludzi i tak nie uczestniczy w organizowaniu nowego społeczeństwa, lecz przystosowuje się do panującego wzorca. Panujący wzorzec determinuje kierunek rozwoju społeczeństwa.

Według nauki Jana Pawła II „Współpraca nad rozwojem całego człowieka i każdego człowieka jest obowiązkiem wszystkich wobec wszystkich". Realizacja rozwoju człowieka i jego kształtowanie są możliwe w klimacie wzajemnego zrozumienia i solidarności. Idea solidarności dominuje w nauczaniu Jana Pawła II i stanowi siłę konstruktywną życia społecznego. Społeczność nie jest przypadkowym agregatem ani skoszarowanym kolektywem, ale stanowi wspólnotę. Kształtowanie człowieka w społeczeństwie to ważny proces rozwoju, wzrostu i zmian. Uświadomienie sobie złożoności i funkcjonalnej współodpowiedzialności jednostki, społeczeństwa i kultury sprawia, że to właśnie osoba, jako jednostka stanowi podstawę wszystkich zjawisk społecznych i kulturowych. Podstawowe potrzeby życiowe jednostki są zaspakajane przez społeczeństwo.

Nasz wspólny dom jest jeden - nasze środowisko, ziemia, przyroda, kosmos - jest wspólnym dobrem całej rodziny ludzkiej. Dobro wspólne jest „sumą warunków życia społecznego" (Sobór Watykański II). Ks. Adam Szafrański potwierdza, że na ową „sumę warunków życia” składa się również nasze środowisko: czyste powietrze, zdrowa woda, nieskażone pożywienie, cisza, zieleń lasów i woń kwiatów $w^{4}$ Środowisko jest szansą pełnego rozwoju osoby ludzkiej i czynnikiem

Tamże, 1983, s.18

4 Tamże, s. 49. 
decydującym o życiu godnym człowieka. Życie i rozwój człowieka nierozerwalnie łączą się ze środowiskiem naturalnym, dlatego według Wróblewskiego wizje natury są przesiąknięte wartościującymi ujęciami przyrody, uzasadniają koncepcję ochrony środowiska i motywują do stosownych działań. Przyrodę w wizjach natury człowiek traktuje jako dobro, które należy chronić, ponieważ jest nośnikiem wartości biologicznych, ekonomicznych, kulturowych, cywilizacyjnych, politycznych i moralnych. W swoich wizjach o sensie ochrony przyrody, czlowiek odwołuje się też do normatywnego pojęcia natury $y^{5}$.

Przyglądając się zmianom w przyrodzie, w gospodarce i życiu człowieka na Ziemi można stwierdzić, że przyroda jest tym, co wpływa na człowieka $z$ wielu stron, od traktowania jej, jako wroga do traktowana jako sacrum. Cała ewolucja ludzkiej myśli o przyrodzie wynika z obserwacji środowiska i wpływa na kształtowanie człowieka. Sobór Watykański powie, że „wszystkie rzeczy z samego faktu, że istnieją mają własną trwałość, prawdziwość, dobroć i równocześnie prawo i porządek, które człowiek winien uszanować ${ }^{\prime \prime}$. To jak czlowiek ustawia i traktuje te rzeczy ma wplyw na jego zachowanie i postawy, a w konsekwencji na kształtowanie jego osobowości.

Ważną sprawą jest zwrócenie uwagi na te części ludzkiego bytu, które nie tylko wiążą człowieka z przyrodą, ale równocześnie wbudowują przyrodę w jego moralną strukturę?. Wszystko co otacza człowieka, kształtuje go. Środowisko przyrodnicze jest stałym elementem w życiu człowieka, tworzy i kształtuje:

- zasady kształtowania się stosunków człowiek-przyroda.

- związki między stanem i charakterem środowiska naturalnego a warunkami i jakością życia człowieka.

Przekonania na jego temat a także na system wartości, jakim dane osoby się kierują wobec niego $\mathrm{w}$ swoim postępowaniu.

Czartoszewski postuluje, że powyższe zależności, jeżeli są uświadamiane, mogą wchodzić w skład światopoglądu człowieka i kształtować świadomość ekologiczną ${ }^{8}$.

Ślipko akcentuje fakt, że „człowiek wchodzi w styczność z przyrodą poprzez swoją cielesność, a czyni to niejako na dwa sposoby. I tak dzięki swej cielesności stanowi cząstkę przyrody, wciela się niejako w jej rzeczywistość, gdyż wyraża swoją istotą jakąś formę jej istnienia. Z drugiej strony ta sama cielesność sprawia, że człowiek, aby mógł żyć jako byt psychofizyczny, nieustannie tej przyrody

5 Por:: Z. WRóblewsKi, (2003), Wartościujące ujęcia przyrody w dobie kryzysu ekologicznego, w.: Konflikty społeczno - ekologiczne, J. Czartoszewski /red./ nr. 5, s. 21-22.

${ }^{6}$ Por.: Sobór Watykański II, konstytucja duszpasterska o Kościele w świecie współczesnym p. 36.

7 Por: T. Ślipko, A. Zwoliński, Rozdroża ekologii, s. 133.

${ }^{8}$ Por.: J. Czartoszewski, (2002), Propedeutyka definiowania i budowania światopogladu ekologicznego, Ateneum Kapłańskie nr 558, s. 267. 
potrzebuje, ku niej się nieustannie wychyla i używa jej odpowiednio do swych potrzeb i zamierzeń. Skala zaś tych sposobów używania przyrody jest niezmiernie szeroka, gdyż wielkie są zapotrzebowania ze strony człowieka, ale też równie bogate możliwości ich zaspakajania"’. Ślipko zwraca uwagę, że przyroda wchodzi w rzeczywistość człowieka i zostaje poddana rządzonym nim prawom, umożliwiając człowiekowi wszechstronne rozwijanie rozumnej aktywności po linii jego moralnych przeznaczeń. Środowisko przyrodnicze przybiera znamiona wartości międzyludzkiej i staje się częścią składową dobra wspólnego społeczeństw ${ }^{10}$.

\section{Edukacja środowiskowa i jej rola}

Edukacja środowiskowa stała się terminem bardzo znaczącym od kiedy raporty o stanie środowiska $w$ sposób dobitny zaczęły informować społeczeństwo o zagrożeniach środowiska i odpowiedzialności człowieka za stan zmiany środowiska. Człowiek w swojej refleksji na temat przyrody dochodzi do różnych wniosków, ale na skutek kryzysu środowiska, czlowiek często odkrywa, że jest częścią natury i że prawdopodobnie jest ona potrzebna jemu do życia i aby przeżyć musi żyć w zgodzie z przyrodą.

Dużym zainteresowaniem odpowiedziało szkolnictwo na potrzeby zmiany świadomości młodego pokolenia, zarówno w edukacji ekologicznej jak i edukacji sozologicznej ${ }^{11}$ oraz w tych aspektach, które się wiążą z szeroko rozumianym środowiskiem ${ }^{12} \mathrm{i}$ harmonijnym współistnieniem.

Edukacja środowiskowa to termin bardzo pojemny. Dołęga ${ }^{13}$ twierdzi, że za tym pojęciem kryje się szeroko rozumiane środowisko, dlatego edukacja środowiskowa, zawiera wiele aspektów (biologiczne, sozologiczne, abiotyczne i społeczne) i właśnie dlatego edukację środowiska umieszcza się zarówno w procesie wychowywania, formowania jak i nauczania.

Edukacja środowiskowa może być jednym z czterech wymienionych przez Prof. Siniarką i Prof. Wolańskiego działów ekologii człowieka ${ }^{14}$ tj: Kulturowe za-

9 Por: T. Ślipko, Granice życia, s. 39.

10 Tamże, s. 41.

11 Sozologia pochodzi od greckiego słowa sodzo, które oznacza ochraniać, ratować, pomagać. Termin ten w 1965 roku wprowadził Walery Goethel.

12 Ochrona środowiska i edukacja ekologiczna w Unii Europejskiej i Polsce /Z.Ciećko i J. Dołęga/, 2003, s. 22

13 J. DoŁĘGA, Filozofia sozologii systemowej, w: Studia Ecologiae er Biothicae, 2/2004, s. 424.

14 A. Sintarska, N. Wolański, Czym jest wspótczesna ekologia czlowieka, w: Studia Ecologiae et Bioethicae, 1/2003, s.79-80. wymienia cztery działy ekologii człowieka tj;1.Filozoficzne problemy relacji człowieka (ludzkości) ze środowiskiem, 2.Przyrodnicze i społeczno-ekonomiczne problemy środowiska człowieka, 3. Środowiskowe (ekologiczne) problemy biologii człowieka, 4. Kulturowe zachowania przystosowawcze, ze szczególnym uwzględnieniem wychowania „do środowiska". 
chowania przystosowawcze, ze szczególnym uwzględnieniem wychowania „do środowiska”. Termin ten może uwzględniać zarówno wychowanie jak i kształtowanie, czyli te etapy edukacji, które w sposób jednoznaczny zaczynają się w rodzinie.

Dołęga wspomina również o „kulturze ekologicznej,, i podkreśla, że aby zaistniała pełna kultura ekologiczna musi zajść wiele zmian w elementach tej kultury tj: nauce, technice i technologii, sztuce i religii ${ }^{15}$.

Jan Paweł II w encyklice Centesimu annus zwracał uwagę na problem niszczenia środowiska ludzkiego i wskazywał na konieczność rozwoju prawdziwej „ekologii ludzkiej”.

Rozwiązań tak bardzo ważnego problemu jakim jest kryzys ekologiczny, należy więc szukać rozpoczynając od wskazania przyczyn tego zjawiska. Skażenia środowiska, wyczerpywanie się zasobów naturalnych, zmiany w bioróżnorodności flory i fauny oraz wiele podobnych naglących problemów to efekty poczynań, które prowadzą do rodziny, do struktur społecznych, politycznych czy ekonomicznych, czy wreszcie do braku określonego celu i sensu życia. Podstawową tych wszystkich struktur jest jednak rodzina i śmiało można powiedzieć, że kryzys rodziny jest początkiem kryzysów innych dziedzin życia ludzkiego. Szafrański pyta „Czyż wezwania ekologów o ochronę ginącego niedźwiadka koala mogą poruszyć serce człowieka, dla którego zabicie własnego nie narodzonego dziecka nie stanowi problemu?" ${ }^{16}$. Reflektując nad przyczynami głębokich, destrukcyjnych zmian w środowisku przyrodniczym i w dialogu międzyludzkim, przychodzi na myśl podpowiedź, że bez solidnego oparcia, jakie może dać rodzina jest niemożliwe zbudowanie trwałych struktur i utrzymanie równowagi pomiędzy licznymi elementami żyjącego świata.

Obrona harmonii w świecie rozpoczyna się w ludzkim sercu. „Początek jest zawsze w sercu poszczególnych osób"17.

\section{Znaczenie i funkcja wychowania}

W dzisiejszych czasach wieloaspektowości i wielości poglądów jest wiele interpretacji znaczenia wychowania i wiele prób jego realizacji.

Socjologowie mówią o kulturowym wzorze osobowości, nowe refleksje wskazują na antypedagogikę, która pomija problematykę ideału. Pedagogika chrześcijańska postuluje powrót do korzeni wczesnych idei wychowawczych głoszonych przez Kościół, opartych na ewangelizacji. Od wieków toczy się w pedagogice spór o proporcje dotyczące tego co przeszłe i tego co ma dotyczyć przyszłości. Zdaje się, że ważne jest określenie elementów stałości i zmienności w wychowaniu.

15 Tamże, s. 426.

16 A. Szafrański, Chrześcijańskie podstawy ekologii, 1993, s. 89.

17 M. SokoŁowski, W stronę ekologii ducha, 2006, s. 17. 
Górniewicz ${ }^{18}$ wymienia dwa pojęcia określające społeczne wyobrażenia ludzi o tym, jakimi mają być w przyszłości ich wychowankowie:

- Kulturowy wzór osobowości,

- Ideał wychowawczy, który jest opisem dojrzałej osobowości człowieka.

Według Bieleckiego ${ }^{19}$ istotnymi elementami procesu wychowania w kształtowaniu i formowaniu dojrzałej osobowości są:

- Miłość dziecka,

- Zrozumienie dziecka,

- Szacunek dla godności człowieka,

- Wspomaganie integralnego rozwoju dziecka,

- Uczenie właściwych wyborów- właściwej hierarchii wartości,

- Wychowanie do odpowiedzialności,

- Wychowanie do samowychowania.

U Cenciniego ${ }^{20}$ wychowanie jest pierwszym elementem poprzedzającym formację i pochodzi od lacińskiego czasownika educere, co oznacza wydobywać, wyciągać prawdę danej osoby, pomóc jej odkryć własną prawdę, to znaczy odkryć kim ona jest, nawet mimo własnej nieświadomości.

Cencini zwraca się do wychowawców, aby zrozumieli, że wychowanie ma w sobie coś Bożego i że każdy wychowawca uczestniczy w stwórczym działaniu Boga. W wychowaniu chodzi o coś, co nie jest łatwe, potrzeba wiele cierpliwości, uwagi, delikatności i świadomości. Planując proces edukacji, często zapominamy o wychowaniu a skupiamy się na wiedzy, na kształtowaniu, na formacji. Cencini uprzedza, że takie formy nie doprowadzą do głębokich motywacji, a o to chodzi w wychowaniu, aby za zachowaniami stały głębokie, szczere motywacje. Jeżeli nie osiągniemy tego w wychowaniu, człowiek nie będzie wykazywał spójnej osobowości, będzie go cechowała niespójność, która ma swoje konsekwencje w życiu człowieka i nie pozwala iść w sposób pełny do ideału. Niespójność jako coś centralnego w życiu człowieka, popycha go do działania w pewien sposób, który może prowadzić go do innych celów niż te, które sobie wyznaczył, bo niespójność oznacza brak integracji.

Cencini twierdzi, że, aby zacząć mówić o formacji i kształtowaniu trzeba mówić o permanentnym wychowaniu, o realizowaniu siebie każdego dnia na nowo. Zwraca uwagę na to, że niespójność, która jest brakiem wychowania, brakiem prawdy ma swoje konsekwencje.

\footnotetext{
18 J. Garniewicz, Kulturowy wzór osobowości w Pedagogika ogólna, Problemy aksjologiczne /red; T.Kukułowicz, M. Nowak, 1997, s. 5-56.

19 J. BeLecki. Wychowanie sznsą rozwoju w kierunku dojrzalej osobowości w Pedagogika - wczoraj, dziś i jutro, Episteme 31(2003). s.36.

20 A. CENCINI, Od wychowania do formacji, 2004, s 22-24.
} 
Cencini wymienia cztery poziomy wykrzywienia percepcji i interpretacji rzeczywistości:

- Wykrzywienie percepcji siebie i swojej tożsamości;

- Wykrzywienie postrzegania Boga, a nawet Jego Słowa;

- Wykrzywienie dotyczące innych ludzi;

- Wykrzywienie dotyczące ideałów życia.

To czwarte wykrzywienie jest szczególnie ważne dla naszych rozważań o wychowaniu do środowiska, ponieważ dotyczy życia społecznego i wspólnotowego oraz sposobów samorealizacji. Często samorealizacja jest łączona z ciągłym sukcesem i aktywnością, ale samorealizacja nie jest możliwa, kiedy jest bezpośrednim celem. Dlatego Cencini przypomina, że samorealizacja jest możliwa tylko jako" niezamierzona konsekwencja transcendentnej intencjonalności życia". Moźliwe jest osiagniecie samorealizacji jako konsekwencji: jeżeli człowiek dąży w życiu do celu, który jest wyższy od niego, który nie identyfikuje się z jego bezpośrednimi celami, a który dąży do elementu transcendentnego. Taka droga człowieka jest realna i prawdziwa, która każe wychodzić z samego siebie, dążýc do czegoś, co jest wyższe od człowieka, co pochodzi z wysoka. Papież Jan Paweł II w jednym ze swych orędzi na dzień modlitwy powiedział, że istota ludzka odkrywa swą tożsamość dopiero wtedy, gdy staje się sługą brata.

Takie doprowadzenie człowieka do dojrzałości spoczywa na nas wszystkich jako rodziców, wychowawców i braci.

\section{Rodzina pierwszą komórką społeczeństwa}

Jan Paweł II w liście do rodzin 1994 [13] zaznacza, że rodzina jest centrum i sercem cywilizacji miłości, mówi też w liście do głów państw 1994 [9], „jestem przekonany, że w rodzinie zawiera się źródło człowieczeństwa".

Potencjał człowieka musi być edukowany, wychowanie do macierzyństwa i ojcostwa to bardzo ważny element troski o człowieka i jego środowisko. W życiu pełnym wyzwań coraz częściej dziecko staje się „dobrem konsumpcyjnym” czy "egoistyczną zachcianką", które ma zaspokoić plany i marzenia swoich rodziców. Takie postawy nie wynikają z troski o dobro dziecka, o dobro człowieka, o dobro przyszłych pokoleń, ale $\mathrm{z}$ realizacji swoich oczekiwań. Ważne jest, aby młodzi ludzie zdawali sobie sprawę z tego, iż czas jest niepowtarzalny. W dzisiejszych czasach trudno jest stosować sztuczne podziały, które jeszcze tkwią w naszej podświadomości i oddzielać w sposób wyraźny i bezkompromisowy obowiązki męskie i kobiece. Prawdą jest, że macierzyństwo biologicznie i psychofizycznie związane jest $\mathrm{z}$ kobietą, ale właśnie dlatego jej zadaniem, jej powołaniem jest skorzystanie z przyrodzonego daru intuicji i nawiązywania więzi, aby pomóc swojemu mężowi dorastać do ojcostwa, „zrobić miejsce” do relacji dziecka z ojcem ${ }^{21}$.

${ }_{21}$ E. Ponorecka, Macierzyństwo w Życie Duchowe, nr 45/2006, s.54. 
Miłości bliźniego trzeba uczyć się od początku, dlatego największa odpowiedzialność „za miłość" spoczywa na rodzicach i rodzinie.

„Rodzina ludzka, ożywiona i podtrzymywana nowym przykazaniem miłości, żyje gościnnością, szacunkiem i służbą każdemu człowiekowi, w którym zawsze dostrzega godność osoby i dziecka Bożego. Winno się to dokonać przede wszystkim i dla dobra małżeństwa oraz rodziny, poprzez codzienny trud tworzenia autentycznej wspólnoty osób, której podstawą jest i którą zasila wewnętrzna komunia miłości" 22 .

Prawdziwa miłość zatacza szerokie kręgi, wykracza poza tych, którzy są we wspólnocie ochrzczonych i w każdym człowieku widzi brata. Warunkiem takiej miłość jest świadomość Bożego obrazu, Bożego podobieństwa w bliźnim i w każdym człowieku.

Jan Paweł II w Orędziu VI Synodu Biskupów do rodzin chrześcijańskich w świecie współczesnym, 12, /24 października 1980 r./ przekazał rodzinom wyjątkowe zadanie; „Do was należy kształtowanie ludzi w miłości i praktykowanie miłości we wszystkich odniesieniach do bliźnich tak, aby miłość ogarniała całą wspólnotę, była przepojona poczuciem sprawiedliwości i szacunku, świadoma swej odpowiedzialności wobec całej społeczności”23.

\section{Społeczne zadania rodziny}

Benedykt XVI swoją encykliką Deus Caritas est chce podkreślić fundamentalną prawdę zawartą w przykazaniu miłości, "aby pobudzić świat do nowej, czynnej gorliwości w dawaniu ludzkiej odpowiedzi na Bożą miłośćn"24, chce skupić się na rozumieniu tego przykazania w celu praktykowania miłości.

Ks. Prof. Dołęga na konferencji naukowej Problemy XXI wieku pt Edukacja środowiskowa a katecheza w dniu 25.10.2006 r. zorganizowanej przez Wydział Filozofii Chrześcijańskiej UKSW /Katedra Edukacji Środowiskowej/ powiedział, że "cywilizacja miłości”, którą tak w swoim nauczaniu rozpowszechniał Jan Paweł II jest „wykwintem ducha”, a my nie możemy wyjść z „cywilizacji śmierci i wojen”, bo jesteśmy zaangażowani dopiero w "cywilizację życia i pokoju” a cywilizacja miłości ciągle jeszcze przed nami. Słowa Ks. Dołęgi są inspiracją do bliższego przyjrzenia się wymowie i przesłaniu przykazaniom miłości.

Jezus zapytany o najważniejsze przykazanie, wymienia dwa: 1 . Będziesz miłował Pana Boga twego, z całego serca swego, z całej duszy swojej, ze wszystkich swych sił, 2. Będziesz miłował bliźniego jak siebie samego.

\footnotetext{
22 Familiaris Consortio. 64

23 Tamże, 64 .

24 DCE, s.7
} 
Kasiłowski podkreśla, że Jezus wskazuje na miłość, względem siebie samego, jako na kryterium miłości bliźniego. „Miłość do nas samych nie polega na mocnych uczuciach, na silnych emocjach, lecz na przyjęciu nas samych z tym wszystkim, co do nas należy i co stanowi o naszej osobie i naszym losie, z naszymi zdolnościami i ograniczeniami. Przejawem miłości do nas samych jest to wszystko, co czynimy dla siebie, realizując siebie w życiu”25. Prawdziwa miłość Boga jest tam. gdzie działa jako miłość bliźniego. Prawdziwa miłość bliźniego zakłada konkretne zaangażowanie $\mathrm{w}$ świecie i w walce o wyzwolenie człowieka $\mathrm{z}$ każdej formy niewolnictwa. Rozumienie sensu miłości jest szansą na godziwe wspólistnienie wspólnoty ludzkiej i jej środowiska.

Pierwszą szkołą bogatego człowieczeństwa jest dom rodzinny. Wiele mówimy o szkolnictwie, edukacji, wychowaniu, prawach dziecka, ale chyba ciągle jeszcze nie jesteśmy świadomi roli rodziny. Kiedy witamy nasze dziecko, staramy się przygotować wszystko co jest potrzebne do jego pielęgnacji, ale znacznie rzadziej uświadamiamy sobie, że witamy osobę z całym bogactwem jej istnienia, że witamy osobę, którą Bóg zawierzył naszej opiece i że to my stanowimy wzorzec postępowania. Dziecko jest wrażliwe na komunikaty emocjonalne rodziców i najbliższego otoczenia, przetwarza je i na nich buduje swoje przyszłe reakcje.

Rodzina głęboko zakorzeniona w środowisko krewnych, znajomych oraz w lokalne struktury społeczne jest bardziej samodzielna, odporniejsza na destrukcyjne wpływy współczesnej kultury w różnych dziedzinach zarówno w dziedzinie moralnej jak i materialnej. Trudności społeczne i materialne oraz rozwiązywanie problemów stają się łatwiejsze w rodzinie scementowanej miłością.

Społeczny charakter rodziny wynika ze społecznego charakteru małżeństwa. Rodzina jako grupa społeczna wyróżnia się spójnością oraz wewnętrzną więzią uczuciową, dlatego stanowi pierwsze ogniwo kulturowe, które ma wpływ na kształtowanie osobowości dziecka. Bóg w określonym czasie, przez rodziców jako pośredników, wyprowadza każdego człowieka na świat. Ks. Szafrański mówi, że podstawy cywilizacji miłości i autentycznej ekologii ludzkiej może kształtować rodzina, oczywiście, kiedy sama stanowi sanktuarium życia i ośrodek kultury życia ${ }^{26}$.

Kościół katolicki szczególnie mobilizuje do intensywnej pracy na rzecz rodzi$n y^{27}$. Rodzina stwarza środowisko kulturowe, które ma wpływ na kształtowanie się osobowości człowieka, ułatwiając proces socjalizacji i wychowania. W ramach kościoła wielokrotnie podkreśla się, że rodzina jest fundamentem społeczeństwa, najmniejszą, ale niezastąpioną grupą ${ }^{28}$. Wpływ rodziny kształtuje charakter

25 P. KasiŁowski, Przykazanie miłości Boga i milości bliźniego w tradycji synoptycznej, w: Warszawskie Studia Teologiczne, X/1997, s. 141-150.

26 A. Szafrański, Chrześcijańskie podstawy ekologii,1993, s.69.

27 Por: A. Streczko, Znaczenie rodziny dla nauczania, Episteme nr. 30, s. 69.

28 Tamże,. s. 71. 
człowieka, urabia wolę i serce i ma znaczenie dla społeczeństwa. W nauczaniu Prymasa i Episkopatu Polski słyszymy, że „rodzina jest optymalnym środowiskiem rozwojowym osoby ludzkiej" ${ }^{29}$. Jest jej kolebką, miejscem pierwszych więzi, umiejętności i obowiązków. Przełożenie poziomu moralności rodziny na realizacje wartości w życiu społecznym ma charakter bezpośredni i fundamentalny i znajduje się u podstaw całego porządku społecznego. Wszystkie formy zachowania i te dobre i te negatywne mają swoje przyczyny i uwarunkowania. Jednym $\mathrm{z}$ istotnych uwarunkowań jest wychowanie dziecka w rodzinnej atmosferze miłości. Od rodziców zależy, czy dziecko ma możliwość zaspokojenia swoich potrzeb i zdobywania pozytywnego doświadczenia, które jest niezbędne dla prawidłowego rozwoju i normalnego funkcjonowania. Działanie wychowawcze z zasady rozciąga się na długi czas, ale jeżeli jest zainicjowane miłością rodziców, to późniejsze treści formacyjne staną się głębokim motywacjami, a nie okresowymi zachowaniami czy postawami. To właśnie rodzice jako pierwsi „kierownicy duchowi" mogą przygotowywać swoje dziecko do dojrzałości, do integralnego rozwoju osobowości, do równowagi we wszystkich trzech sferach; fizycznej, psychicznej i duchowej. Jeżeli rodzina nie spełnia oczekiwań dziecka, może stać się źródłem społecznego nieprzystosowania ${ }^{30}$. Prawidłowo funkcjonująca rodzina jest dobrym fundamentem zdrowego społeczeństwa.

\section{Przygotowanie do edukacji ekologicznej w rodzinie}

W rodzinie już od wczesnego dzieciństwa można uczyć się prawdziwej miłości przez okazywanie sobie szacunku, czułości, gotowości do wzajemnego służenia sobie. Rodzice nawet ci bez wiedzy ekologicznej, mogą w wyniku tylko samych działań wychowawczych przygotować dziecko do rozumienia treści pojawiających się w późniejszym procesie edukacji środowiskowej i bogatego w treści merytoryczne kształcenia szkolnego. W domu rodzinnym można przybliżyć i pokazać:

- Ideę harmonii i wzajemnego wspólistnienia ludzi i środowiska,

- Rolę człowieka i jego wpływ na środowisko oraz konsekwencje egoistycznego myślenia,

- Umiejętność troski o najbliższe środowisko,

- Poszukiwanie prawdy o człowieku i świecie,

- Rozumienie, że nie ma złotego środka i niekwestionowanych prostych rozwiązań,

- Zobaczenie złożoności świata przyrody,

29 Por.: W. Dymek, Rodzina wedtug serca Bożego, Miesięcznik Kościelny Archidiecezji Poznańskiej, nr. 3, s. 482 .

30 Por.: J.BIELECKI, Wychowanie szansa rozwoju w kierunku osobowości dojrzałej, Episteme 31 (2003) , s. 33-34. 
- Sens przygotowania do odpowiedzialnych i aktywnych postaw obywatelskich,

- Głęboki wymiar czlowieczeństwa opartego nie tylko na umiejętności współżycia $z$ innymi, ale przede wszystkim bycia dla drugiego.

- Świadomość o bezwarunkowym darze z siebie.

\section{Podsumowanie}

Rozwiązań tak bardzo ważnego problemu jakim jest kryzys ekologiczny, należy szukać rozpoczynając od wskazania przyczyn tego zjawiska. Skażenia środowiska, wyczerpywanie się zasobów naturalnych, zmiany w bioróżnorodności flory i fauny oraz wiele podobnych naglących problemów to efekty poczynań, które prowadzą do rodziny, do struktur społecznych, politycznych czy ekonomicznych, czy wreszcie do braku określonego celu i sensu życia. Podstawą tych wszystkich struktur jest jednak rodzina i śmiało można powiedzieć, że kryzys rodziny jest początkiem kryzysów innych dziedzin życia ludzkiego w tym kryzysu ekologicznego. Ważne w wychowaniu i edukacji środowiskowej jest przygotowanie do współżycia z przyrodą i do szanowania ludzkiego środowiska życia. Twórcze towarzyszenie młodemu człowiekowi w drodze, jaką powinien przebyć od momentu poczęcia do momentu osiągnięcia zintegrowanej osobowości, takiej, aby w praktyce codziennego życia realizował poprzez swoje zmotywowane postawy „dojrzały światopogląd ekologiczny” zaczyna się od rodziny i jej współdziałania $z$ innymi. Osobiste dojrzewanie człowieka dokonuje się nie w izolacji lecz we współdziałaniu.

\section{SUMMARY}

Solutions to such an important problem as ecological crisis should be sought starting with indicating reasons for such a situation. Contamination of the environment, using up the natural resources, changes in biodiversity of flora and fauna and many other similar urgent problems are the effects of actions which lead to family, social, political or economical structures, or also lack of specified aim or sense in life. The basis for all these structures is nevertheless the family and it can be easily said the family crisis is the beginning of crisis in other areas of human life also ecological crisis.

It is important in bringing up and environmental education to prepare for coexistence with the nature and to respect humans' habitat.

Creative companionship with young people in the road which they should take from the moment of conception to the moment of achieving an integrated personality, such that in the practice of everyday life he would realize through his motivated posture "mature ecological outlook on life" starts with the family and cooperation with others. Personal growing up of human beings takes place not in isolation but in cooperation with others. 